Brit. F. vener. Dis. (1974) 50, 404

\title{
The American perspective
}

\author{
R. R. WILLCOX \\ St. Mary's Hospital, London, and King Edward VII Hospital, Windsor
}

The views expressed by Evans (1974), Oriel (1974), and Watt (1974), in their three most interesting, perceptive, but of necessity short papers presented at the Medical Society for the Study of Venereal Diseases in January, 1974, were broadly similar to those of the recent International Travelling Seminar on Venereal Disease in the U.S.A. (Brit. F. vener. Dis., 1973) - namely in praise of the laboratories, both research and serological, but critical of many of the clinics in comparison with some found elsewhere, particularly in Britain.

It is necessary, however, that the present American venereological scene should be viewed in the broader perspective of their enormous achievements in our subject, direct and indirect, many of which today tend to be taken for granted. The author's first professional visit to the United States was made early in 1946 (Willcox, 1946a, 1946b, 1946c, 1951); his tenth and most recent was late in 1971 when he had the task, as Rapporteur-General, of co-ordinating the preparation of the report of the IUVDT Travelling Seminar (WHO, 1973; PAHO, 1974).

This paper attempts to review some of the American achievements during this quarter century and to emphasize the fact that there is little that the venereologists of the world do in their daily lives in 1974 that has not been initiated or influenced by our American friends.

\section{The great syphilologists}

Sorely missed today on both sides of the Atlantic, through death and retirement, are the giant clinical syphilologists Stokes (with his associates Beerman and Ingraham) in Philadelphia, Earl Moore in Baltimore, and Evan Thomas in New York. They ran large hospital centres and all were extremely kind to the young visitor from England. These men, together with Kampmeier, wrote the 'bibles' of modern syphilology (Kampmeier, 1943; Moore,
1944; Stokes, Beerman, and Ingraham, 1944; Thomas, 1949). Stokes was a most prodigious author and 'Modern Clinical Syphilology', by the Philadelphia Group, is not only a collector's item today but is frequently consulted some $\mathbf{3 0}$ years after for the information that only it contains.

These physicians researched, taught, and wrote (and in Stoke's case wrote again) on all aspects of syphilis. In the years which followed, Moorewho continued for longer-had a very great influence, not only through his textbooks but personally, on a considerable number of now senior British venereologists who stayed for varying periods at Medicine I at Johns Hopkins and visited his home. This influence still persists and has contributed to a marked degree to the linking of venereology with general medicine in the hospitals of Great Britain.

That these leaders have not been replaced is largely due to the discovery of penicillin, enabling syphilis to be treated with less expertise than was previously required, to the decline in prevalence of the disease and particularly of its late manifestations, and also to the long-standing separation of gonorrhoea from syphilis in the university centres of the U.S.A. which has rendered difficult an evolutionary diversification into other sexually-transmitted diseases. In 1973 in the U.S.A. there were 25,080 reported cases of primary and secondary syphilis and 40,931 of late and late latent disease (Amer. Soc. Hlth Ass., 1974), while in the earlier heyday of clinical experience there were no less than 107,924 cases of the former in 1946 and 251,958 of the latter in 1943 (USPHS, 1973).

In his last years, even Earl Moore had to interest himself in the wider field of chronic diseases. His journal-the American fournal of Syphilis, Gonorrhea, and Venereal Diseases, which for decades had been foremost in the world-came to be replaced in the mid-fifties by the Fournal of Chronic Diseases. Although he continued as editor of this new journal, his devotion to venereology persisted, and he even accepted for his new periodical in 1955 an article from the author on non-specific urethritis! 


\section{Antibiotics}

\section{PENICILLIN}

We are rightly extremely proud of the British discovery of penicillin by Fleming (1929) and of Florey, Abraham, and Chain who developed it (Chain, Jennings, Florey, Orr-Ewing, Gardner, Heatley, and Sanders, 1940), but owing to the urgency of war Florey had to take it to the United States to overcome quickly the problems of rapid large-scale commercial production. Most British venereologists who were the first to use penicillin were those in the Forces who cadged it from nearby American units (as did the author in West Africa, although a local brew was made in his routine laboratory by Major K. R. Hillnow Professor of Pathology at the Royal Free Hospital -which had very slight but demonstrable activity).

It was Mahoney, Arnold, and Harris (1943) at Staten Island, New York, who after studies on rabbits were first to use the antibiotic against syphilis on four Norwegian sailors. No one doubted the statistical significance of this small series and the Americans started a mass study, on a co-operative clinical group basis, to demonstrate its profound effects upon the disease. The first reports were presented in 1946 at the National Institutes of Health in Washington at a large meeting chaired by Earl Moore, which occasioned the author's first visit, as an Army observer.

It was the Americans who showed the falling off of results which was occasioned, in striving for greater purity of the early commercial penicillins, by the unconscious inclusion of more of the relatively ineffective penicillin $K$ than of the effective penicillin G (see Willcox, 1947). The widespread availability of crystalline penicillin $G$ soon followed as did the book 'Penicillin in Syphilis' by Moore (1947).

The need for a repository penicillin for the treatment of venereal diseases was recognized from the outset, and it was quickly provided by Romansky and Rittman (1945) with penicillin in oily beeswax, soon to be followed by procaine penicillin and procaine penicillin in oil with aluminium monostearate (PAM) by Buckwalter and Dickison (1948) and later by benzathine penicillin (Szabo, Edwards, and Bruce, 1951).

These American developments made 'one shot' treatments possible not only for gonorrhoea and venereal syphilis but also for other treponemal diseases. They were applied world-wide in the many mass campaigns organized for the World Health Organization through the mediation of Thorstein Guthe, against yaws, pinta, and endemic syphilis; over 47 millions have now been treated as clinical or latent cases or as contacts, and these campaigns have led to a dramatic fall in prevalence (Guthe and Idsøe, 1968).

The conversion of penicillin $G$ to penicillanic acid by Sheehan and Henery-Logan (1957) and the synthesis of phenoxymethyl penicillin (penicillin $\mathrm{V}$ ) were the first steps leading to the many newer synthetic penicillins.

It must also be remembered that the earliest assessments of penicillin allergy were made in the U.S.A., where the first anti-histamine drug ('Benadryl') came into use in 1945, followed by numerous others, the commercial introduction of penicillinase, and the many advances in steroid chemistry; the Americans have been throughout in the forefront of allergy research (e.g. the Shelley degranulation and other tests).

\section{OTHER ANTIBIOTICS}

Success in producing other antibiotics has been predominantly American. The commercial introduction of penicillin was followed in succession by streptomycin (developed by Waksman), chloramphenicol, chlortetracycline, oxytetracycline, tetracycline (and more recently doxycycline, minocycline, and other tetracyclines), erythromycin, spectinomycin, and nystatin -all of which are used in venereology-, as well as numerous others which are not.

While it could be argued that today we could manage well with European drugs such as benethamine penicillin, some of the newer penicillins, spiramycin, rifampicin, cotrimoxazole, and the orally administered drugs for trichomoniasis, how many of these would have been developed so quickly without the American developments described ? Conversely, none would have been possible in the first place without Ehrlich, Domagck, and above all Fleming, not to mention the considerable contributions of other European workers, including expatriates and immigrants from that continent in the United States. Nevertheless, by any count, the American contribution has been immense.

\section{Serology of syphilis}

Before the second world war and for some years afterwards, the simpler alternative or additional serum test for syphilis to the European-developed Wassermann reaction (Wassermann, Neisser, and Bruck, 1906) was the American test of Kahn (1922) which soon achieved world-wide usage; although it is now outdated, it is still used in a few places to the present day. Kahn's quantitated test gave enormous assistance in the management of early syphilis and in diagnosing suspected cases of early congenital syphilis. The 
importance of standardized techniques was emphasized by Kolmer (1922) in his modification of the Wassermann test.

Mary Pangborn and her associates at Albany, N.Y., isolated cardiolipin in 1942 (Pangborn, Maltaner, Tompkins, Beecher, Thompson, and Flynn, 1951), and since that time the Americans have completely dominated the serological scene. Harris, Rosenberg, and Riedel (1946) introduced the VDRL test (which should be called the Harris test as the Venereal Disease Research Laboratory at Staten Island has long since been shut down), and this, or one of its modifications, is the test most often used throughout the world today. Reagin tests were further simplified for mass testing by the Rapid Plasma Reagin (RPR) Card test (Portnoy, 1963).

The introduction by Nelson and Mayer (1949) of the treponemal immobilization (TPI) test provided the first specific test for treponemal disease. The fluorescent treponemal antibody (FTA) test (Deacon, Falcone, and Harris, 1957) was followed by the FTAAbsorption (FTA-ABS) test (Hunter, Deacon, and Meyer, 1964) and the monospecific FTA-ABS IgG and IgM tests in congenital syphilis (see Scotti, Logan, and Caldwell, 1969).

Further simplifications were achieved at the Center for Disease Control, Atlanta, by automation or partial automation of the procedures described and also of the Treponema pallidum haemagglutination test. The automated reagin test (ART), which provides a permanent record by precipitation of carbon particles on a moving band of filter paper, is the present albeit expensive end-point for the laboratory performing large numbers of tests (McGrew, Decros, Stout, and Falcone, 1968).

In addition, the Americans have provided a model example by their adoption of standardized techniques and their serological control of the many State laboratories from a central reference centre (in recent years from Atlanta by Genevieve Stout, Virginia Falcone, and Aldwida Wallace). The serological manuals prepared for the State laboratories in Atlanta are widely used (USPHS, 1969). International serological cross-testing had been undertaken in the U.S.A. many years before those covered by this review. The necessity for a national reference centre has gradually been accepted throughout the world.

While the Wassermann, and subsequently a number of reagin tests, including the Price precipitation reaction, and several others with the Reiter treponeme came out of Europe, and the Treponema pallidum haemagglutination test out of Japan, and like the Wassermann reaction itself some of the American procedures are developments of work begun in other lands, no other single country can match this record of performance. If the Americans had no other venereological achievements than those of syphilis serology they would still have every reason for just pride.

\section{Treponemal research}

Basic clinical research on the course of human syphilis has been provided in the U.S.A. by experimental inoculation (Magnuson, Thomas, Olansky, Kaplan, De Mello, and Cutler, 1956) and by the Alabama study, started in the 'thirties' (Pesare, Bauer, and Gleeson, 1950). Even the Gjestland monograph (1955) in Norway was assisted by research grants from the United States Public Health Service.

In more recent times we have had the discovery of treponemes in the aqueous humour from Miami (Smith and Israel, 1967), which supplemented the earlier findings of such organisms in the lymph nodes and spinal fluid by Collart, Borel, and Durel (1962) in Paris. Not to be forgotten either are the philosophical writings of Hudson (1946) who, on the basis of clinical observations and the earlier views put forward by Butler (1936) in Guam, drew the endemic treponematoses together under one heading.

In animal syphilis the Americans have dominated the scene, but not without some competition from Paris, Lyon, Bucharest, Moscow, and elsewhere. The work of Turner and his colleagues, including Hardy, Nell, and Hollander, whose laboratories became the WHO International Treponematosis Centre at Baltimore, and provided much of the attraction for visitors to Johns Hopkins, has been foremost. Their monograph on 'The Biology of the Treponematoses' (Turner and Hollander, 1957), embracing endemic syphilis and yaws, is definitive.

Consistently prominent throughout have been the Public Health Service Venereal Disease Research laboratories, first at Staten Island, New York, then at Chapel Hill, North Carolina, and latterly at the Center for Disease Control at Atlanta, Georgia (see Willcox, 1971), where the laboratory has now been absorbed into the general institution.

Basic studies, including those of the effects of penicillin and other antibiotics in the rabbit, were undertaken by Arnold, Eagle, Fleischman, Hardy, Magnuson, McLeod, Nell, Turner, Walter Clark (still at Atlanta), and others, including Yobs, in these laboratories and elsewhere, e.g. at Houston, Texas, by Knox and Izzat, while in Los Angeles, Miller, apparently alone in the world apart from Metzger and Smogór (1969) in Poland, continues his work towards a syphilis vaccine (Miller, 1971). 
Treponemal disease has also been extensively studied in other animals. The earlier work of Rosahn (1952) on the mouse was followed by studies on the hamster by Turner and Hollander (1957) at Baltimore. More recently, at the unique Primate Facility at Chamblee, Georgia, pinta has been successfully transferred to the chimpanzee by Kuhn, Varela, Chandler, and Osuna (1968). Much work has also been done on oral and other non-pathogenic treponemes, e.g. by Rosebury and Foley (1941).

\section{Gonorrhoea}

In the days of the giant syphilologists the counterpart for gonorrhoea was Pelouze (1939) with his concept of tissue susceptibility and his large work of reference on the subject.

Since then there have been many attempts at improved or simplified diagnosis, some not successful enough (e.g. the use of the dipstick), others somewhat more so, comprising new serological techniques (see Norins, 1971). Recently screening programmes for gonorrhoea have been organized on a massive scale (over a quarter of a million females were screened in 1971: Bradford, 1971).

Perhaps the most important advance has been the introduction of the Thayer-Martin selective medium (Martin, Thayer, and Peacock, 1964), which with its local modifications is now widely used throughout the world. Apart from improving routine diagnosis it has also resulted in the not infrequent finding of the gonococcus in the mouth, which Pelouze considered to be largely unsusceptible. Secondly, the definition of colony types of virulent and non-virulent organisms by Kellogg, Peacock, and Deacon (1964), also at Atlanta, has accelerated much research aimed at improved diagnostic tests and investigations into the possibility of immunization. Thirdly, we have the transfer of gonorrhoea to the chimpanzee (Lucas, Price, Thayer, and Schroeter, 1967) which at last provided an experimental animal model.

On the treatment side, it was the Americans who introduced "one shot" therapy and before 1950 repository penicillins were available for this purpose in sterilized disposable plastic syringes (see under Antibiotics).

Today much important work is being done throughout the country on the clinical and epidemiological aspects of gonorrhoea, by Fiumara, Greenberg, King Holmes, Pariser, Schroeter and their colleagues, and by Kraus, Sparling, and others on the laboratory side (see Med. clin. N. Amer., 1972).

\section{Other sexually-transmitted diseases}

NON-GONOCOCCAL URETHRITIS

Studies of Mycoplasma have continued since the work of Dienes and Smith (1942) and particularly since the discovery of the $T$-strain by Shepard (1956); more recently their possible role in foetal death has been considered.

The initiative regarding the role of Chlamydia in this condition, however, has certainly come from London, first from Harkness (1950), then from Barrie Jones and Dunlop and their colleagues whose important work is well known. The condition is not recorded statistically in the U.S.A. and many individual American physicians deny that it is a real problem, although in an appendix to the book by Harkness (1950) can be found the reports of American investigations conducted amongst their armed forces in the Far East and at home which indicated its considerable prevalence.

\section{TRICHOMONIASIS}

France-with metronidazole-led the way to other newer products.

\section{GENITAL HERPES}

In this field the extensive work of Nahmias, Josey, Naib, Luce, and Guest (1970) and other groups led to its suspected association with cervical cancer.

\section{CHANCROID, LYMPHOGRANULOMA VENEREUM, and} GRANULOMA INGUINALE

The descriptions of Greenblatt, Pund, Sanderson, Torpin, and Dienst (1953) of these rarer diseases remain valuable basic reference material. Indeed, in spite of more recent descriptions of extensive numbers of cases of granuloma inguinale from Southern India, and Papua New Guinea, and of smaller numbers elsewhere, there has been little to add to the published findings of these workers, apart perhaps from the concept of Goldberg (1964) that its causative organism is primarily a bowel inhabitant which secondarily involves the traumatized skin.

\section{Contact-tracing}

Although the importance of contact-tracing was recognized by Harrison in the first world war (King, 1974), contact-tracing techniques were first being extensively applied in the U.S.A. in far gone prepenicillin days at a time when they were regarded with suspicion in Britain as likely to lead to a breach in confidentiality. They have been developed and evaluated on defined indices, and a dedicated corps of men has been trained for the purpose, some of 
whom have at times mapped out extensive local chains of infection which are seldom emulated elsewhere.

It was the Americans, too, who once penicillin became available, quickly demonstrated the value of the epidemiological treatment of contacts (Alexander and Schoch, 1949; Plotke, Eisenberg, Baker, and Laughlin, 1949). Not only was this extensively applied in the United States, but it became a sine qua non for success in the WHO-assisted campaigns against the endemic treponematoses.

\section{Health education and propaganda}

The Americans likewise were the quickest to appreciate the scope of the propaganda value of modern mass media. In 1946, Dr. H. Bundersen, the then very energetic chief of the Health Department in Chicago, had 600 workers engaged on such matters. The author (Willcox, 1946c) wrote at this time, 'VD control in Chicago is almost a religion. Street-cars blazon the current slogan, "Don't be an ostrichFace the facts" ... and matches given away free with cigarettes are apt to bear similar propaganda, urging one to "Ring the City Health Department, Extension VD." The VD Control Department has squads of eagle-eyed representatives concerned with the tracing of contacts, while electric typewriters rumble quietly in the background. If the returns indicate that a particular bar or hotel is subscribing too freely to the numbers of patients under treatment, then the proprietor is visited and asked to "cooperate in VD control". Should he fail to do so, the premises can be shut down by the Health Department and notices like "VENEREAL DISEASEBEWARE" and "SYPHILIS-KEEP OUT" are plastered up outside. Proprietors usually co-operate'.

Then trucks equipped with sound equipment playing boogie woogie music toured the South, while films, gramophone records, radio programmes, newspapers, and magazine were all widely used. In Georgia, brilliant coloured signs brought the message 'THE TREATMENT OF EARLY SYPHILIS WITH PENICILLIN IS COMPLETED IN NINE DAYS'. One's reaction in those days was that 'Few can imagine some of these American methods being used here'.

Not to be forgotten either are the international studies of Webster (1970), who demonstrated the paucity of hours spent on the subject in the education of students, particularly in the medical schools of developed countries.

The American Social Health Association (originally The American Social Hygiene Association) has been in the forefront as a non-governmental agency.
It established the Snow Award, named after its founder Dr. William Freeman Snow, 1874-1950 (f. vener. Dis. Inform., 1950), which is given to those who have made a significant contribution to the service to humanity in the field. To date there have been two British holders, Colonel L. W. Harrison and Mrs. Neville Rolfe.

\section{International relations}

The two largest international venereological meetings in the United States were convened by the United States Public Health Service. The first, held in 1956, as C. A. 'Larry' Smith was completing his term as Chief of the VD Program, filled the Statler Hotel in Washington (USPHS, 1956). The Russians had been invited and there was some speculation whether they would arrive. They did come, a little late, and there was a splendid reception in their honour at the Roumanian Embassy.

The second was held in 1962, under the auspices of W. J. 'Bill' Brown; it was organized with the declared assistance of the World Health Organization through Thorstein Guthe, the International Union against the Venereal Diseases and Treponematoses, the American Social Health Association, and the American Venereal Diseases Association. There were some 1,500 participants from more than fifty nations (USPHS, 1964). Recalled at this meeting is the impact of the paper by Collart of Paris, who presented the then sensational findings of persistent treponemes. This latter meeting, too, laid particular emphasis on behaviouristic aspects, yet another field in which the Americans have led the way, through the pioneering studies of Kinsey, Pomeroy, and Martin (1948) and Kinsey, Pomeroy, Martin, and Gebhard (1953), which are being continued at Bloomington, Indiana.

In recent years further international meetings have been organized by the American Social Health Association and Pfizer Laboratories at St. Louis, Missouri, in 1971 (see ASHA, 1971) and 1972, and at New Orleans in 1973.

Twice the Americans have invited groups of overseas experts to study, evaluate, and report on their methods. The first study was undertaken in 1949 by a WHO Study Commission (WHO, 1950) and the second in 1971 when 21 overseas physicians comprised the International Travelling Seminar (WHO, 1973); once again, in the closing days at Atlanta, they came under the much appreciated auspices of "Bill" Brown. Here they were invited to discuss their findings with the National Commission on Venereal Diseases which was about to prepare a report of its own evaluations and to make recommendations. 
No account of international relations can be complete without reference to America's greatest venereological ambassadress at the Regional Office for the Americas of the International Union, at the American Social Health Association's offices in Broadway-namely Jo Tuller. Her never flagging effervescence and warmth attracted and cemented the friendship through the years of virtually every overseas worker on the subject who visited the city.

\section{Clinic facilities}

Criticism of overcrowding and unattractive premises of some clinics is not a recent observation. The author wrote of the Chicago VD clinic in 1946 that it was probably the most used venereal disease clinic in the world, some 1,300 persons passing through its doors each day. (This huge number was occasioned by the daily treatments or frequent injections then required).

'Over twenty persons of both sexes can be dealt with simultaneously. The clinic is in a converted school, and the actual buildings are not anything marvellous. Its clientèle are black and white of all grades of society. The main waiting room is like a station on a Bank holiday, while in the treatment room a small corps of doctors deals with patients as fast as they can go in the twelve centrally-operated cubicles'. In 1944 some 23,500 cases of venereal disease were treated there compared with 870 in 1918, the first year of operation. The larger figure is now well exceeded for all sexually-transmitted diseases at some other centres, including St. Mary's in London, but the Chicago figures 30 years ago would have been virtually entirely composed of cases of syphilis and gonorrhoea.

\section{Conclusions}

The U.S.A. have a problem as regards venereal disease and this was responsible for their own reappraisal of their entire programme by a National Commission (Webster, 1973). The peak reported rate per 100,000 for primary and secondary syphilis of 75.6 in 1947 fell to a low point of 3.8 in 1957 , but rose again to 11.7 (or 3.1 times the low point) by 1972-USPHS (1973) (in England in 1972 the rate was 2.56-Dept. Hlth Soc. Sec., 1973). For gonorrhoea the earlier peak reported rate of 284.2 per 100,000 in 1947 fell to $129 \cdot 3$ in 1958 but by 1972 had soared to 349.7 (in England in that year it was 115.28). Moreover, four-fifths of actual cases were unreported and the realistic number of cases of primary and secondary syphilis has been estimated as 85,000 and that of gonorrhoea as $2 \frac{1}{2}$ millions (Amer. Soc. Hlth Ass., 1973).
Nevertheless, in Great Britain also, our own cases of infectious syphilis have increased to approximately $2 \cdot 7$ times their previous low figure and our cases of gonorrhoea have also surpassed the early post-war peak.

Our advantages are that we are geographically a small country rendering a compact network of clinics easier to achieve, and above all that we have socialized medicine. Although the clinics were municipally run and nationally supervised before the introduction of the National Health Service in 1948, the general switch to free treatment in all hospital specialties and in general practice also, has led not only to an improved status of venereologists with an acceptance of equality to consultants in other specialties, but also in recent years to a long-awaited improvement in facilities. Both have led to the acceptance by most patients with venereal disease of treatment in hospital clinics rather than in private practice, although the latter is still available. However, as pointed out by Mr. Ambrose King in the discussion that followed the three papers by Evans, Oriel, and Watt, it is not long since many of our own clinics were dingy and overcrowded, as indeed some of our hospitals still are. As long as medicine, as in many countries, is practised on a private basis, venereal disease control at least is at a disadvantage. If, in the future, routine clinical facilities in the U.S.A. are extended to embrace all sexually-transmitted conditions as well as gonorrhoea and syphilis, it can be expected that the Americans also will be confronted with mounting statistics of non-specific and other infections which, in their case, could add up to several more millions.

The Americans are a hospitable, friendly, forthright, and forthcoming people, entirely frank in presenting their problems, warts and all. They have always apparently been impressed by size, and in some ways at the present time seem to take an inverted pride in presenting their problems as bigger and their warts as larger than those of others. They are also modest about their achievements and the object of this paper has been, in part, to redress this attitude. It is appreciated that there have been many omissions for which the author offers his apologies to those concerned. British venereologists, if in smarter premises, should not forget that all but a few of the diagnostic tests they employ, the drugs they use, and the methods by which they are given-even the syringeswould not have come, or would have arrived much later, had it not been for American drive and expertise.

\section{References}

AleXander, L. J., and Schoch, A. G. (1949) Arch. Derm. Syph., 59, 1 
AMER. Soc. Hlth Ass. (1971) 'The VD Crisis'. N.Y.

— (1974) 'Today's VD Problem-1974'. N.Y.

Brit. F. vener. Dis (1973) 49, 184

BRADFORD, W. R. (1971) Paper presented at National Venereal Disease Conference, Atlanta

Buckwalter, F. H., and Dickison, H. L. (1948) f. Amer. pharm. Ass., 37, 472

BUTLER, C. S. (1936) 'Syphilis sive morbus humanus'. Science Press, Pennsylvania

Chain, E., Jennings, M. A., Florey, W. H., OrREwing, J., Gardner, A. D., Heatley, N. G., and SANDERS, A. G. (1940) Lancet, 2, 226

Collart, P., Borel, L-J., and Durel, P. (1962) Ann. Inst. Pasteur, 102, 693

Deacon, W. F., Falcone, V. H., and Harris, A. (1957) Proc. Soc. exp. Biol. (N.Y.), 96, 477

Department of Health aNd Social Security (1973) 'Report of the Chief Medical Officer for the Year 1972', p. 67. H.M.S.O., London

Dienes, L., and Smith, W. E. (1942) Proc. Soc. exp. Biol. (N.Y.), 50, 99

Evans, B. A. (1974) Paper presented at a meeting of the MSSVD on January 25, 1974

Fleming, A. (1929) Brit. f. exp. Path., 10, 226

GJESTLAND, T. (1955) Acta derm.-venereol. (Stockh.), 35, Suppl. 34

GolDBERG, J. (1964) Brit. f. vener. Dis., 40, 140

Greendlatt, R. B., Pund, E. R., Sanderson, E. S., ToRPIN, R., and DIENST, R. B. (1953) 'Management of Chancroid, Granuloma inguinale, Lymphogranuloma Venereum'. U.S. Department of Health, Education and Welfare. Public Hith Serv. Publ. 255. Washington, D.C.

GuTHE, T., and IDSøE, O. (1968) Brit. F. vener. Dis., 44, 35

HARKNESS, A. H. (1950) 'Non-gonococcal urethritis'. Livingstone, Edinburgh

HarRis, A., Rosenberg, A. A., and Riedel, L. M. (1946) F. vener. Dis. Inform., 27, 169

Hudson, E. H. (1946) 'Treponematosis'. Oxford University Press, N.Y.

Hunter, E. F., Deacon, W. E., and MeYer, P. E. (1964) Publ. Hlth Rep. (Wash.), 79, 410

f. vener. Dis. Inform. (1950) 31, 242 (Obituary notice of W. F. Snow)

KaHN, R. L. (1922) Arch. Derm. Syph., 5, 570

KAMPMEIER, R. H. (1943) 'Essentials of Syphilology'. Lippincott, Philadelphia

Kellogg, D. S., Peacock, W. L., and Deacon, W. E. (1964) WHO Document VDT/Neisseria 4/64

KING, A. J. (1974) Brit. F. vener. Dis., 50, 391

Kinsey, A. C., Pomeroy, W. B., and Martin, C. E. (1948) 'Sexual Behaviour in the Human Male'. Saunders, Philadelphia

,,--- , and Gebhard, P. H. (1953) 'Sexual Behaviour in the Human Female'. Saunders, Philadelphia

Kolmer, J. A. (1922) Amer. f. Syph., 6, 82

KuHN, U. S. G., VARELA, G., ChandLER, F. W., and Osuna, G. G. (1968) f. Amer. med. Ass., 206, 829

Lucas, J. B., Price, E. V., Thayer, J. D., and Schroeter, A. (1967) New Engl. F. Med., 276, 1454
McGrew, B. E., DeCross, M. J. F., Stout, G. W., and Falcone, V. H. (1968) Amer. F. clin. Path., 50, 52

Magnuson, H. J., Thomas, E. W., Olansky, S., Kaplan, B. I., De Mello, L., and Cutler, J. C. (1956) Medicine (Baltimore), 35, 33

Mahoney, J. F., ARnold, D. C., and Harris, A. (1943) Amer. F. publ. Hlth, 33, 1387

Martin, J. E., Thayer, J. D., and Peacock, W. L. (1964) WHO Document. VDT/Neisseria 5/64

Med. clin. N. Amer. (1972) 56, No. 5 Symposium on Venereal Disease, ed. B. Webster

MetZger, M., and SMOGøR, W. (1969) Brit. f. vener. Dis., 45, 308

MilleR, J. N. (1971) In 'The VD Crisis', p. 78. Amer. Soc. Hlth Ass. and Pfizer Laboratories, N.Y.

Moore, J. E. (1944) 'The Modern Treatment of Syphilis'. 2nd ed. Thomas, Springfield, Ill.

— (1947) 'Penicillin in Syphilis'. Thomas, Springfield, Ill.

Nahmias, A. J., Josey, W.E., NaIb, Z. M., Luce, C. F., and Guest, B. A. (1970) Amer. F. Epidem., 91, 547

Nelson, R. A., and MAYeR, M. M. (1949) f. exp. Med., 89, 369

NoRINS, L. C. (1971) Paper presented at National Venereal Diseases Conference, Atlanta

ORIEL, J. D. (1974) Paper presented at a meeting of the MSSVD on January 25, 1974

Pan-AMERICan Health Organisation (1974) 'Report of the International Travelling Seminar in the U.S.A.'

Pangborn, M. C., Maltaner, F., Tompkins, V. N., Beecher, T., Thompson, W. R., and FlynN, M. R. (1951) 'Cardiolipin Antigens'. WHO Monograph Ser. No. 6, Geneva

Pelouze, P. S. (1939) 'Gonorrhoea in the male and gonorrhoea in the female', 3rd ed. Saunders, Philadelphia

Pesare, P. J., Bauer, T. J., and Gleeson, G. A. (1950) Amer. F. Syph., 34, 201

Plotke, F., Eisenberg, H., Baker, A. H., and LAUghlin, M. E. (1949) f. vener. Dis. Inform., 30, 252

Portnoy, J. (1963) Amer. F. clin. Path., 40, 473

Romansky, M. J., and Rittman, G. E. (1945) New Engl. F. Med., 233, 577

Rosahn, P. D. (1952) Arch. Derm. Syph. (Chicago), 66, 547

Rosebury, T. and Foley, C. (1941) Proc. Soc. exp. Biol. (N.Y.), 47, 368

Scotti, A., Logan, L., and Caldwell, J. G. (1969) $\mathcal{F}$. Pediat., 75, 1129

Sheehan, J. C., and Henery-Logan, K. R. (1957) $\mathcal{f}$. Amer. chem. Soc., 79, 1262

SHEPARD, M. C. (1956) $\mathcal{f}$. Bact., 71, 362

SMIth, J. Lawton, and Israel, C. W. (1967) $\mathcal{F}$. Amer. med. Ass., 199, 980

StOKES, J. H., BEERMAN, H., and INGRAHAM, J. R. (1944) 'Modern Clinical Syphilology', 3rd ed. Saunders, Philadelphia

Szabo, J. L., Edwards, C. D., and Bruce, W. R. (1951) Antibiot. and Chemother., 1, 499

Thомаs, E. W. (1949) 'Syphilis: Its Course and Management'. MacMillan, New York 
TURner, T. B., and Hollander, D. H. (1957) 'Biology of the Treponematoses'. WHO Monograph Ser. No. 35, Geneva

U.S. Public Health Service (1956) 'First International Symposium on Venereal Diseases and Treponematoses'. Current Literature on Venereal Disease, special issue

(1964) 'Proceedings of World Forum on Syphilis and other Treponematoses, Washington D.C. 1962', Public Health Service Publication 997 (1969) 'Manual of tests for Syphilis, 1969'. U.S. Department of Health, Education and Welfare, Atlanta

$$
\text { (1973) 'VD Fact Sheet-1972'. Atlanta }
$$

WASSERMANN, A., NeISSER, A., and BRUCK, C. (1906) Dtsch. med. Wschr., 32, 745
Watt, L. (1974) Paper presented at a meeting of the MSSVD on January 25, 1974

WEBSTER, B. (1970) Brit. f. vener. Dis., 46, 156 (1973) Ibid., 49, 141

WILlCox, R. R. (1946a) Brit. F. vener. Dis., 22, 102 (1946b) Brit. med. F., 2, 825

(1946c) St. Mary's Hosp. Gaz., 52, 35

(1947) Brit. F. vener. Dis., 23, 11 (1951) Publ. Hlth (London), 64, 44 (1971) WHO Documents: WHO/VDT/RES 71. 244; WHO/VDT/RES/GON 71. 57

World Health ORganization (1950) 'Venereal Disease Control in the U.S.A.'. WHO Tech. Rep. Ser., No. 15, Geneva

(1973) VDT Document, WHO/VDT/73. 386 (Brit. F. vener. Dis., 49, 184) 